\title{
Nonhuman and Human 'Victims' and 'Perpetrators' Intra-active InSecurity Becomings of the Ebola Outbreak
}

\section{By Theresa Ammann}

\begin{abstract}
Although feminist theory and security studies have long criticized post-war gendered meta-narratives that categorize people as either victims or perpetrators based on their (imagined) insecurities, these criticisms have mainly focused on the agency of humans, but have dismissed nonhuman entities as irrelevant. This article explores this binary by assessing the victim- and perpetrator-hood dynamics of nonhuman and human matter during the Ebola outbreak in Liberia. Drawing on Karen Barad's agential realism, I assess these dynamics by means of three vignettes of inSecurity becoming in peri-urban Liberia. The vignettes are based on ethnographic fieldwork, individual and focus-group interviews, and solicited diaries. This agential realist exploration provides the following new insights into understandings of victim- and perpetrator-hood: (1) nonhuman entities can emerge as victims and perpetrators; (2) victim- and perpetrator-hood are not exclusive states of existence but relational processes of intra-actively emerging becomings; and (3) both insecurity and security emerge concurrently through the entangled becoming of victim and perpetrator. These insights require further research to reconsider concepts such as intentionality, responsibility and ethics in discussions of war, post-conflict justice and humanitarian and peacebuilding efforts.
\end{abstract}

\section{KEYWORDS}

Agency, Agential Realism, Liberia, Security Studies, Victim-Perpetrator Binary

Theresa Ammann is a Postdoctoral Fellow in the Human Security section of Aarhus University's Anthropology Department. In her PhD dissertation, she explored a postHuman security approach that transverses critical, feminist, and human security studies in the context of post-conflict and post-Ebola Liberia. Her current project focuses on restorative justice and conflict mediation in Denmark. 


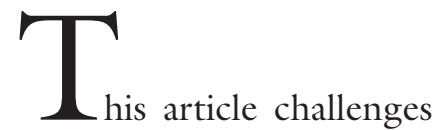

the given assumptions of victim- and perpetrator-hood ${ }^{1}$ that permeate the media, politics, and some academic accounts by introducing nonhuman matter into the debate over the Ebola virus and disease. I explore three accounts of humans and nonhumans who (in)directly experienced Ebola during the 2014-2016 outbreak in Liberia. Drawing on Karen Barad's agential realist understanding of agency as "a matter of intra-action" $(2007,178)$, I assess the intra-actively emerging inSecurity becomings of human and nonhuman matter, as they give insights into agency, relationality, and the emerging dynamics of victim- and perpetrator-hood.

In combining Barad's posthumanist framework - agential realism - and established scholarship on the victim-perpetrator binary in feminist theory and feminist, critical, and human security studies, I challenge given assumptions of victim- and perpetrator-hood by means of an agential realist analysis of the Ebola phenomenon. While existing critiques of the victim-perpetrator binary have dismantled its gendered nature as failing to account for lived realities, I argue that it is crucial to include nonhuman matter in this discussion as nonhuman and human matter are entangled in their intraactive (inSecurity) becoming. This article's more nuanced readings of victim- and perpetrator-hood are also valuable given that media portrayals of the Ebola outbreak openly construe people as either helpless victims or malicious perpetrators of the spreading of the virus.

This article shows that humans and Ebola both emerge as 'victims' and 'perpetrators'; both kill one another in their respective struggles to survive. This is not meant to offend or to diminish the immense sufferings and hardships that Ebola caused, but rather to call attention to the fact that Ebola's intra-actions brought about both security and insecurity. I refer to this as 'in-
Security becoming' to underline the continuous, entangled becoming of insecurity and security. Thus, I argue that victim- and perpetrator-hood are not exclusive states of existence but emerging processes of becoming that emerge through one another and are both secure and insecure at the same time. As victims and perpetrators emerge through intra-active entanglements of humans and nonhumans, their experiences are relational.

I begin by exploring the victim-perpetrator binary in feminist theory and security studies to illustrate the absence of nonhuman entities. I then introduce Barad's posthumanist understandings of intra-action, to develop my postHuman Security understanding of inSecurity becoming, and of agency, to account for nonhuman entities in victim-perpetrator discussions. This allows an agential realist analysis of three vignettes' of victim- and perpetrator-hood dynamics during the Ebola outbreak. I conclude by discussing the wider implications of my analysis.

\section{Victim- AND PERPETRATOR-HOOD IN FEMINIST THEORY AND \\ SECURITy STUdies}

Understandings of the notions of 'victim' and 'perpetrator' are all too often defined in relation to agency as mutually exclusive states (Connell 1997, 121). Since humanists define agency as the autonomous, intentional ability of humans to transform or influence the world (McNay 2016, 39-40), this has resulted in a misconception of perpetrators as active, agentic subjects that cause harm to passive, non-agentic victims and objects (Alcoff and Gray 1993, 271). The media, activists, and mental health workers have aggravated this misconception even further by demarcating passive victimhood as a state of long-term mental suffering that is mostly experienced by 
women (Lamb 1999, 115). This not only misconstrues lived realities, it also denies the pervasive existence of victimization and fails to understand the structural political and social causes of abuse (ibid., 131).

To overcome this passive reading of victimhood, some prefer the term 'survivor' to 'victim' to underline people's active ability to act and respond (Lamb 1999; Govier and Verwoerd 2004). However, this concept fails to realise that one's ability to act is always constrained or enabled by context and power relations (McNay 2016, 41). It misreads survival as the primary goal of existence, denies the importance of other values such as wellbeing, love, and self-fulfilment, and fails to see that not all victims survive (Nissim-Sabat 2011, 164-5).

Critical theorists argue that we must undo the structural violence of our existence rather than dismiss the use of 'victim' (Schott 2015, 191). However, since understandings and usages of 'victim' and 'perpetrator' are constructs of socio-cultural and discursive practices (Lamb 1999, 3), we can question the oft-assumed givenness of the terms and seek alternative understandings of them.

'Victim' and 'perpetrator' are equally central concepts in debates over war and peacebuilding in security studies. Since victims experience insecurities caused by perpetrators, allocating victim- and perpetratorhood is essential to provide post-war aid and justice. However, as in feminist theory, since understandings of 'victim' and 'perpetrator' are defined in relation to 'agency', they have misconstrued victims as passive women and perpetrators as aggressive men (Moser and Clark 2001, 3). This heteronormative portrayal essentializes women as victims, denies them the ability to exercise agency, treats women as a homogenous, victimised group (Hudson 2016), associates them only with peace, fails to account for women who create insecurities (Wibben 2011) and perpetuates the inequalities it intends to undo (Schott 2013, 19).
Victim- and perpetrator-hood often bleed into one another or change over time as many people resort to violence not intentionally, but due to the complex social, political, economic, and environmental structures and lived realities that define their lives (Govier and Verwoerd 2004). Some victims also produce victims, for example, child soldiers (Enns 2012).

Wider relational structures of insecurities are thus experienced not only by victims but also by perpetrators. To understand experiences of victim- and perpetrator-hood in security studies, we must clarify our approach to and understanding of security, as they remain varied and contested. I therefore draw on three nontraditional approaches: feminist, human, and critical security studies.

Unlike traditional realist approaches, which focus on military and state security, feminist security studies argue that realist understandings are elitist as they exclude female, marginalised and oppressed perspectives (Tickner 1992; Enloe 2014). Feminist security scholars argue that security has both personal and private aspects (Enloe 2014). Gender and security are both fluid constructs of (power) relations, discourse, society and culture that form lived experiences (Henry 2007). The critiques of the victim-perpetrator binary mentioned above largely derive from feminist security scholars.

Developed by policymakers, human security studies argue that security must be people-centred and broadened to include personal, political, economic, food, health, environmental, and community insecurities (Haq 1994). These seven interconnected securities highlight the fact that security covers not only survival - i.e., freedom from need - but also people's freedom to live life in dignity and free from fear. People, states and structures are all agentic sources of (in)security.

Finally, critical security studies challenge the realist assumption that concepts such as 
security describe externally-existing realities. They argue instead that these concepts affect realities and must therefore be altered to change the unequal existence of the present (Mutimer 2017, 54). Unlike human and feminist security studies, which have largely focused on humans, critical security studies have recently turned to matter and posthumanism (Fierke 2016).

Since I seek to challenge the given assumptions of victim- and perpetrator-hood in the context of the Ebola outbreak, this turn to posthumanism is relevant. Since understandings of victim and perpetrator are entangled with understandings of agency, different readings of agency enable alternative understandings of victim and perpetrator. And, given that Ebola is nonhuman, my analysis can benefit from a posthuman reading of agency. Seeking posthumanist understandings of agency aligns with Hudson's attempt to decolonise Western individualistic readings of agency in peacebuilding by turning to Afrocentric understandings of agency as being deeply relational, socially embedded and historically formed by humans and nonhumans (2016, 202). In turning to posthumanism, I ask what insights emerge into victim- and perpetrator-hood and into the (in)securities causing and surrounding them?

\section{Agential Realism AND INSECURITY BECOMING}

Influential posthumanist thinker Karen Barad's agential realism challenges all binary thinking - e.g., human/nonhuman, culture/nature, internal/external, matter/ meaning. They demonstrate that all matter - e.g., human, nonhuman, meaning, matter, nature, culture, emotions - is mutually articulated $(2007,26)$. These articulations emerge through material-discursive practices that continuously (re)create differences. All matter is, thus, not stable but continuously produced and producing (ibid., 137).
Thus, our existence is not autonomous, as "[i]ndividuals do not preexist their interactions" but continuously emerge through their entangled intra-actions (ibid., ix). ${ }^{2}$ Since existence is an entangled process of becoming that continuously emerges through the intra-actions of matter (ibid., 383 ), we can no longer speak of or identify a linear causality between subject and object (ibid., 175). Instead, causes and effects emerge through intra-actions (ibid., 214).

Barad's posthumanist agency differs starkly from humanist readings of agency. For Barad, agency is not a property, nor is it dependent on subjectivity or intentionality, but rather " a matter of intra-acting; it is an enactment", it “is 'doing' or 'being' in its intra-activity (...) Agency is about changing possibilities of change" (ibid., 178). Agency thus includes all matter in its mutually entangled becoming. Since beings are not autonomous, no singular entity can have agency; instead agency emerges through intra-actions, and it is through these that we can observe agency at work (ibid., 254). These intra-actions produce phenomena that constitute our reality; thus, phenomena replace beings or things as primary ontological units of analysis (ibid., 139).

Through the entanglement of agential realism and the approaches to security mentioned above, a new postHuman Security approach emerges. Taking a critical approach, I turn to posthumanism to challenge and reconceptualise existing understandings of (in)security. Since everyone and everything is entangled in a continuous intra-active becoming, both insecurity and security are continuously emerging through the intra-actions of all human and nonhuman matter. They constitute an ongoing process of inSecurity becoming which $\mathrm{co}^{-}$ produces and is co-produced by all matter. "InSecurity becoming" describes the fact that we can never speak of absolute insecurity or security, but instead only of moments that are becoming more inSecure than inSecure and vice versa. ${ }^{3}$ Furthermore, 
inSecurity becoming is not experienced by individual humans but relationally by all matter. ${ }^{4}$ Feminist security's bottom-up integration of the marginalised is thus extended to include nonhuman matter, while human security's seven (in)securities are redefined as countless forms of inSecurity becoming.

InSecurity becoming and agential realist agency provide new understandings of victim and perpetrator. (1) Since agency includes all matter in its intra-active becoming, and since humans are not the pure causes or effects of inSecurity becoming, all matter can emerge as both victim and perpetrator. (2) Agential realism rejects the binary opposition of victim and perpetrator as exclusive states of being. Instead victimand perpetrator-hood are processes of becoming that are (re)produced and emerge through each other and their intra-active entanglements. Experiences of victim- and perpetrator-hood are thus relational and fluid. (3) The assigning of passive object- and active subject-hood to victims and perpetrators does not describe an independently existing reality but is co-produced by and $\mathrm{CO}^{-}$ produces material-discursive practices. (4) No singular truth about victim- or perpetrator-hood can be unveiled, as the two are inseparably entangled and continuously becoming. (5) Since perpetrators cause the inSecurity becoming experienced by victims, the intra-actively produced inSecurity becoming of the Ebola phenomenon constitutes my unit of analysis. I rely on inSecurity becomings as materializations of the Ebola phenomenon, as I could not interview or observe the Ebola virus.

Agential realism is thus relevant for my analysis for two reasons. First, agential realism allows an assessment of complex empirical findings where various discursive and material forces are at play (Højgaard and Søndergaard 2011, 338-339). For Barad, it is central to understand how nonhuman and human matter co-produces and is $\mathrm{CO}^{-}$ produced by phenomena, subjectivities and potentialities of change (ibid., 342). Since the Ebola outbreak was suddenly brought about by the Ebola virus, it almost demands a posthuman analysis, as we must understand how nonhuman and human matter simultaneously co-produces and is co-produced by the becoming of inSecurity. Ebola illustrates why it is so crucial to treat nonhuman matter on a par with human matter since it is mutually constitutive of the inSecurity phenomenon rather than solely an added effect or cause of it.

Secondly, while existing feminist theory and security studies have disproved the existence of a victim-perpetrator binary and several essentialized assumptions connected with it, I seek to expand this by means of agential realist contributions. With this postHuman Security approach in mind, I explore how relational inSecurity becoming is experienced by nonhuman and human matter and how this co-produces and is coproduced by victims and perpetrators. Since all matter can co-produce or be co-produced by inSecurity becoming, it can intraactively emerge as victim or perpetrator. However, victim- and perpetrator-hood are not stable states of being but intra-active processes of continuous becoming. While most regard Ebola as the sole perpetrator of the epidemic that co-produced severe inSecurity becoming, my analysis shows that both humans and Ebola emerged as both victims and perpetrators and that both insecurities and securities - i.e., inSecurity becoming - emerged through their intra-actions.

The postHuman Security that I propose here emerged after data collection. As I reread my data, a bridge between agential realism and my security studies background began to emerge. Faced with people's complex experiences of (in)security regarding Ebola, I soon realized the ill-fitting nature of binaries, such as security-insecurity and victim-perpetrator, and the importance of integrating nonhuman matter. 


\section{Methodological Context}

To study how the Ebola phenomenon's inSecurity becoming coproduces and is coproduced by the victims and perpetrators of all matter, I draw on ethnographic data in the form of participant observation, informal individual and focus-group interviews, and solicited diaries written by eight key informants collected over four months between 2014 and 2015 in eight peri-urban Monrovian communities.

My nonhuman and human informants included schools, teachers, students, roads, market-women, shop-owners, sex-workers, homes, the internet, letters, news, local civil-society groups, the community chairman, governmental employees, (former) soldiers and rebels, and many more. Method as experimentation is essential to study the relationality of matter and discourse (Aradau et al., 2015, 7, 75) and my experimenting with different methods and (non)human informants provided various written, spoken and observed data to study their relationality.

The in- and exclusions I have made are inevitably influenced by the fact that I am part of the phenomenon under observation (Højgaard and Juelskjær 2012). My selection of the three vignettes exemplifies this. I chose Grace, as her human-nonhuman intra-actions seemingly illustrate more conventional understandings of victim and perpetrator. ${ }^{5}$ Conversely, I chose Mary's human-nonhuman intra-actions ${ }^{6}$ and the nonhuman-nonhuman intra-actions of Ebola and a school ${ }^{7}$ since they challenge conventional understandings of victim- and perpetrator-hood. The latter two vignettes do not describe the majority of experiences, but nonconforming, untold narratives that challenge assumed victim-perpetrator and insecurity-security binaries.

To minimise the power imbalance between researcher and researched (see Buch and Staller 2014, 125), I shared my opinions with my informants to make us both subjects of scrutiny. Thus, we both emerged as both researchers and researched, and our knowledge-production emerged through our intra-actions.

Through our intra-actions, I also began to deeply care about my informants. As the vignettes reveal, 'friendship as a method' provides the most private insights (Tillmann-Healy 2003). However, I sought to abstain from romanticizing their accounts to give the reader truthful, critical insights. I have altered all names and identifying information to ensure their security and anonymity.

\section{LIBERIA}

Liberia's history provides an essential backdrop to Ebola's inSecurity becoming. The country was founded in 1847 by freed American slaves, referred to as settlers. The settlers soon became the oppressors of native Liberians and established a one-party rule that lasted for 130 years. Deprived of the right to education and of the right to vote for most of this period, native Liberians overthrew the settlers in a coup in 1980. A nine-year period of autocratic and violent rule ensued, followed by a civil war that lasted from 1989 to 2003, with a violent interim 'peace' from 1997-1999. Although international peacebuilding efforts have taken place since 2003, Liberia ranks poorly in the UN Human Development Index, with weak governmental and judicial systems, high levels of corruption, food shortages, poor health conditions and low literacy rates.

Ebola entered this context in March 2014. My fieldwork had begun two months earlier and was suddenly upended by my university's decision to recall me from Liberia. International news and efforts (except for pre-existing health NGOs) paid little attention to Ebola until August 2014, when two American health-workers contracted the virus and were airlifted back home. Subsequently, international efforts became involved because of the fear of a 
global epidemic. Several countries halted flights to Liberia, and international companies withdrew their workers from the three affected countries. As imports came to a halt, Liberia's weak economy collapsed, food prices began to skyrocket and a food crisis erupted. Ebola's ensuing inSecurity becoming and the consequent victim- and perpetrator-hood are explored in three vignettes.

\section{An Agentic Ebola Survivor}

Since Grace, a 28-year-old illiterate marketwoman, had mainly faced ostracism from her community, friends and husband ever since she had returned from the Ebola Treatment Unit (ETU) as an Ebola survivor in October 2014, she was shy and withdrawn whenever we met. At the peak of the Ebola outbreak in August 2014, it fell to Grace to nurse her sick brother and parents. Once they had passed away, she began to show Ebola symptoms herself. With no one to care for her - her husband had fled the house out of fear of contracting Ebola - she sought help at an ETU. Although Ebola wrecked her body and mind, Grace survived. But when she returned home, everyone treated her with fear, "They think I'm still Ebola!" Their fears were exacerbated by reports of Ebola survivors passing on Ebola through their semen and breastmilk months after they had been declared healthy. As global research into Ebola remains sparse, advice varies, leaving people confused as to how to intraact with survivors. And while the ETU gave Grace a document declaring her to be Ebola-free, Ebola continued to influence her life. Her joints and eyes often hurt, and she could neither work as hard nor earn as much as she used to. Her community's ostracism forced her to travel long distances to be able to sell her produce to people who were not afraid of her. She did not enjoy life as she used to. She was now caring for her brother's five orphaned children, and her husband still feared her, so she struggled alone to make ends meet for the family. Ebola was not Grace's past, but it had sedimented into her present and future. Through the pains and ostracism, it lived on through her and continuously coproduced her inSecurity becoming.

Grace's intra-action with Ebola conveys a sense that Ebola solely created insecurities, as no securities beyond the fact that Grace survived seem to exist. Ebola limited Grace's options, and it is unclear how she will overcome this moment of immense inSecurity. Her story illustrates how the Ebola phenomenon redrew the boundaries of inequality along the lines of race, class and gender. First, due to my university paying my flight ticket and my visa-friendly passport, I had a greater chance to escape the virus in March, when it was slowly establishing itself. Grace, on the other hand, had no such affiliation, financial means or passport. Secondly, being financially constrained, Grace was unable to afford health advice from expensive, private hospitals. Similarly, information was sparse, and illiterate people like Grace had to rely on rumours and radio news to make decisions about the virus. Thirdly, Ebola was deeply gendered. Women like Grace were more closely involved in caring for the sick and thus more likely to expose themselves to the virus. Similarly, women comprise the majority of sales people (low-income jobs), while men are more likely to work in highincome positions as, for example, public clerks or teachers. During the Ebola outbreak, this not only placed women in direct physical contact with people on a regular basis, it also resulted in greater economic deficits, as most sales decreased, while men could often sustain their incomes, as they did not depend on perishable produce $\left(\mathrm{Ko}^{-}\right.$ rkoyah and Wreh 2015). Grace's refusal to take her relatives to an ETU shows that family and love are essential in a country where political distrust remains high and health institutions are known to be poor. 
While Grace's economic, food and personal inSecurity becomings have been worsened by her suddenly becoming a mother of five, she works hard so they can go to school. She knows that if they, unlike her, go to school and obtain better paid jobs, they will be her ticket out. From her initially apparently stable insecurity, she is actively changing the possibilities of change for her nephews and thereby herself.

The dimensions of victim- and perpetrator-hood in this case are varied. While her parents were victims of Ebola, they emerged as perpetrators in their entanglement with Ebola, as it was through them that Grace contracted the virus. Grace was a victim of Ebola (the perpetrator), which threatened to kill her and continues to create the inSecurity becoming that she and her family experience. Since she personifies the virus to her community and husband, they have ostracized her as a potential perpetrator spreading Ebola. This makes her a victim of their ostracism and illustrates that victimhood goes beyond survival. Grace's vignette shows how perpetrator and victim emerge through one another and create relational inSecurity becomings.

\section{Ebola's Positive Change}

With her bright spirit, Mary, a 33-year-old, literate owner of a roadside store, and I became instant friends. Mary had returned to Monrovia with her husband Joshua shortly after the peace agreement had been signed. Her once-loving husband started to come home late at night, drunk, and smelling of female perfume. His business ventures increasingly took him out of town, but their money dwindled. When Mary finally confronted him about his infidelity, he became angry and physically violent. Although he apologised, he fell into the same pattern whenever Mary confronted him. She chose to remain silent but suspected him of having a second family. Most of Mary's friends had similar marriages. Their husbands kept several girlfriends on the side, and many of them encouraged Mary to take a lover of her own. As a good Methodist, this idea appalled her. To her, her husband's behaviour was the result of Liberian culture, his friends, or some jealous person who had placed charms on him. While Mary was continually thinking whether to stay with or leave Joshua, she knew little about judicial law in relation to divorce and custody. Since she wanted their three children to continue their education, and as she feared that the one filing for divorce had to cover all the expenses, she had secretly been saving up money for years. And while many children stay with their mother following a divorce, she feared, like many, to lose them. Mary continued to gather evidence of Joshua's infidelity and violent behaviour, such as recordings of his phone conversations and photos of her battered body, to prepare for any eventualities. Her inSecurity becoming emerged through her phone.

When Ebola hit their intra-action, it further entrenched distrust and fear between them and reconfigured their relationship. Having previously contracted sexually transmitted diseases from Joshua, Mary was terrified of contracting Ebola and denied him sex for months. She was convinced that Ebola was able to spread so quickly because of the "promiscuousness of Liberian men". Joshua must have had similar fears, as he increasingly spent time at home. During the Ebola outbreak, they had to make precarious decisions between their family starving or their potentially coming into contact with the virus in crowded market places. The family quickly adopted advised measures and self-quarantined when a friend fell ill with Ebola only days after Mary had met her. Unsure whether money could spread the virus, they sprayed banknotes with chloride. Nevertheless, Ebola provided Mary with new possibilities when an ETU opened up close to her store, and her sales began to increase. In the hope of liberating herself financially from Joshua, 
she continued to steadily increase her secret savings.

Unlike Grace, Mary was not directly touched by Ebola, and her inSecurity becoming varies starkly. While Mary was at great risk of contracting Ebola in her shop and had to sustain her family despite rising food prices, Ebola also reconfigured her relationship with Joshua. Ebola, through the ETU near her store, enabled her to sustain herself and increase her savings in an effort to acquire a better future. In this sense, Ebola is not the conventional perpetrator that only creates insecurities. This agential realist, non-linear causality shows us that Ebola's entangled intra-actions have farreaching consequences that go beyond the purely negative. The Ebola phenomenon discriminated along lines of class, as Mary's literacy allowed her access to information that Grace did not have, and her well-situated shop increased her savings.

While Mary feared becoming a victim of Ebola, this did not happen. Instead Ebola's wider intra-actions enabled her increased financial independence from Joshua. As a victim of domestic violence, it is interesting that Mary does not see Joshua as the perpetrator of her experiences but instead blames the Liberian culture, her husband's friends, and evil charms. Similarly, Mary did not fear contracting Ebola only from people or animals, but also from money. That is, the list of potential nonhuman perpetrators is extended to Ebola, culture, charms, and money. Her case illustrates Ebola's inSecurity becoming: while she was in danger of becoming a victim of Ebola, she emerged unharmed and benefited from Ebola's entanglements in the form of the financial inflows from the presence of the ETU.

\section{SECURITY In Insecurity}

During my four months of fieldwork, I worked as a volunteer teacher at a private community school called EPU. I received the position through friends, a married couple - the headmistress and a board member of EPU - who also taught there. The school had been founded by a German NGO in a refugee camp in Ghana and had been brought back to Liberia by my friends. In 2014, the school had become self-sufficient and was comprised of one longhouse with five classrooms, two of them shared by two classes. Eight teachers taught ninety students from Years 1 to 8 . Since the government had closed all schools for six months in an effort to halt Ebola, I feared that EPU might have suffered.

As Ebola spread, community efforts became increasingly efficient at curbing Ebola. Thus, Mercy Corps, a global humanitarian agency, designed a locally run Ebola response programme. Through a friend working at the Foreign Ministry, the headmistress heard that Mercy Corps was seeking to partner with local NGOs. From seventy other such organizations, EPU was selected and its teachers, who had been unemployed and struggling due to EPU closing, were trained and hired as mobilisers. They visited communities to listen to people's beliefs about and reactions to Ebola and then taught them how to improve them. People were then encouraged to act out certain scenarios, like how to handle a sick person. Additionally, mobilisers left buckets and soap in predominant public spaces to increase hygiene. Since mobilisers were known to communities and built on people's existing knowledge, the response was very successful at building concrete response skills, dispelling false rumours about Ebola, and saving lives.

Ebola's intra-action with EPU brought about numerous inSecurity becomings. Due to EPU's closure, students had to redo entire school years, thus causing a great financial burden to their families. However, the teachers received higher salaries as mobilisers for Mercy Corps. For six months, they were able to sustain their families, and some even managed to save up money. The 
headmistress was able to ensure her family's security by continuing with the construction of their house. Their financial standing also increased spending within the community, thus benefiting it. EPU was given a jeep to access other communities, and mobilisers received new phones that they were allowed to keep upon the project's completion. EPU's reputation in the community rose immensely, and by 2015 student numbers had risen to 130 . This increase is impressive, since EPU competes with five other small community schools. The increase in finances allowed EPU to hire two extra teachers, refurbish its facilities and add a nursery. EPU also received ordinary schoolbooks from Mercy Corps. It also hired two women to prepare food for children in recess. Prices are kept low to ensure the food security of students who cannot afford food or get enough food at home. EPU's board members hoped to benefit from their international connections and struck up meetings with other potential international funders for an adult literacy project. EPU's reputation as a school with international partners has also stimulated great gender aspirations within the community. The headmistress's success in manoeuvring EPU through Ebola has established her as a big woman. Parents of girls in particular send their children to EPU because they want them to be as educated and well-achieving as the headmistress. As a role model for young girls, she has set an example for what they can achieve. Similarly, the addition of the nursery allows mothers - predominantly the carers of children to focus on their jobs. These are crucial steps in a country that is struggling with gender inequality. Thus, the intra-active inSecurity becoming of Ebola and EPU affected students, teachers, communities, school facilities, the livelihoods of newly hired staff and their families, educational standards, gender aspirations, and food and economic inSecurity in the community. However, other schools in the community suffered hardships during Ebola. EPU's inSecurity becoming illustrates Ebola's discrimination along lines of class, due to the headmistress's connections with the Foreign Ministry and her education.

The inSecurity becomings of the nonhuman-nonhuman intra-action of EPU and Ebola illustrate how victim- and perpetrator-hood emerge through one another, but can also go into reverse and extend to nonhuman matter. While EPU was at first a victim of Ebola (due to the school's closure), it disabled Ebola's existence through its intra-action with Mercy Corps, thus, making EPU the 'perpetrator' and Ebola the 'victim.' This vignette demonstrates clearly how inSecurity becoming is experienced relationally, as the whole school and community were affected. Similarly, it illustrates how victim- and perpetrator-hood emerge through one another and how they can quickly go into reverse if not recreated through intra-active entanglements.

\section{INSECURITY BECOMINGS OF Victims AND PERPETRATORS}

Although many security scholars treat security and insecurity as stable states of being, my analysis shows that they are both continuously emerging at once; they form an inSecurity becoming. The various cases of inSecurity becomings also illustrate the continuously changing dynamics of victimand perpetrator-hood.

In saying this, I do not mean to deny the immense insecurities that Ebola created, the lasting negative effects that persist, the traumatic experiences that haunt millions of people and, most importantly, the thousands of lives that were taken. All these matter. Yet even something as horrifying as Ebola cannot be thought of solely in a black and white manner. These inSecurity becomings call for more nuanced and complex understandings of victim- and perpetrator-hood that include human and nonhuman matter, since we cannot disentangle 
one human's inSecurity becoming from the inSecurity becoming of other human and nonhuman entities.

While feminist theory and security studies have long challenged and disproved the gendered binary portrayal of victim-andperpetrator that persists in politics and the media, they have focused on domestic and (post)war violence between humans. My posthuman analysis has integrated nonhuman matter and analysed the dynamics of victim- and perpetrator-hood in the context of the Ebola outbreak.

The three vignettes show that victim and perpetrator emerge through the multiple, entangled intra-actions of humans and nonhumans. Since everyone and everything is always intra-acting/doing agency, this posthuman understanding of victim and perpetrator - defined in relation to posthuman agency - is free from passivity. Thus, all victims are agentic. However, they are never only insecure or secure, as their continuously changing intra-actions enable and disempower them all at once. Victim and perpetrator emerge (unintentionally) through their wider entanglements with humans and nonhumans and co-produce inSecurity becoming.

In their intra-action with Ebola, Grace's parents emerged first as victims and later as perpetrators when they passed on the virus to Grace. And while Grace survived the virus, its after-effects continue to victimize, her since her community continues to see her as a potential perpetrator spreading the virus. As a survivor of Ebola, Grace continues to be a victim of Ebola; existence goes beyond survival and needs love and wellbeing.

Mary, a victim of domestic violence, does not see her husband as the perpetrator of her experiences but blames Liberian culture, his friends, and charms. Instead of victimizing her, Ebola's intra-actions enabled her financial liberation and improved her future choices over whether to leave her husband or stay with him.
Finally, EPU's intra-action with Ebola shows how two nonhuman entities emerged as victim and perpetrator and quickly reversed their dynamics when EPU became involved in halting Ebola's existence. Again, experiences of inSecurity becoming were relational, as they stretched beyond the school into the wider community.

As structural inequalities are continuously (re)produced, Ebola redrew existing inequalities of gender, class, race, education, and knowledge networks. Literacy, a marker of class, influenced whether people had to rely on the Ebola rumour mill, like Grace, or were able to find alternative knowledge platforms and affiliations, like Mary and EPU.

Victim- and perpetrator-hood are relational. Grace's inSecurity becoming is experienced by her and her family and emerges in relation to her community. And, like all Liberians, Mary was a potential victim of Ebola, as she was at risk of contracting the virus and being affected by its wider intraactive becomings of inSecurity. EPU's initial victimhood was experienced by the school, its teachers, its students, and their wider networks.

But Ebola's perpetrator-hood was equally relational, as the virus was not the sole cause of these inSecurity becomings. The first nonhuman-human transmission from an infected bat to a toddler would not have been enough for the epidemic to occur. One of many 'causes', the dilapidated health system - financially and physically inaccessible to most people - enabled Ebola's rapid spread.

This posthuman reading of victim- and perpetrator-hood has several implications for future research. Taking an agential realist approach, future research will have to redefine intentionality and responsibility in the context of victim- and perpetratorhood, as the focus has to move from blaming single individuals to investigating relational intra-actions. While this might seem 
controversial, it is not too far from what judicial courts in some countries already take into consideration when defence lawyers draw on the past of perpetrators to explain their actions; the window of responsibility includes not only the moment of the crime, but also the wider entanglements. Moral judgements should be based on intentions and actions (Barad 2007, 23). Furthermore, future research should investigate the human and nonhuman dynamics of victim- and perpetrator-hood in contexts of war, post-conflict justice, peacebuilding and humanitarian efforts. Such discussions are complex and controversial but needed to improve the practices of researchers and practitioners.

This article presents a first explicit posthumanist proposition as to how we might rethink the victim-perpetrator binary eventually to overcome it and its inaccurate usage. In analysing the inSecurity becomings of the Ebola outbreak, I have challenged binary assumptions about victimand perpetrator-hood and shown that both nonhuman and human matter can (unwittingly) emerge as perpetrator and/or victim through their intra-actions. Victim- and perpetrator-hood are thus relational processes through which inSecurity becomings emerge.

In challenging existing concepts and the victim-perpetrator and security-insecurity binaries, this article shows that we are all part of a complex, continuous becoming. Once we accept the more complex realities of our existence, future research can enable us to move towards more ethical becomings.

\section{Notes}

1. 'Perpetrator-hood' is a term borrowed from Derluyn et al. (2015).

2. Intra-action replaces interaction to preclude the assumption of prior existence and underscore that our relational existence emerges through intra-actions $(2007,33)$.
3. A body's momentary experience of inSecurity might be deceiving, as cancerous cells could be growing inside it, or inSecurity may emerge in the next moment.

4. An analysis of relational inSecurity becoming is particularly valuable in Liberia, where every person is for someone, and people rely on bonds of allegiances (see Bledsoe 1980).

5 . Based on interviews and participant observation conducted in November 2015.

6. Based on interviews and participant observation conducted in February to April 2014 and November 2015 and her solicited diary from November 2015 .

7. Based on interviews and participant observation conducted in February to April 2014 and November 2015 and solicited diaries written by the headmistress, one board member, and two teachers in November 2015.

\section{REFERENCES}

- Alcoff, L. and Gray, L. 1993. Survivor Discourse: Transgression or Recuperation? Signs: Journal of Women in Culture \& Society. 18(3), 260-290.

- Aradau, C., Huysmans, J., Neal, A. and Voelkner, N. 2015. Critical Security Methods: New Frameworks for Analysis. Routledge.

- Barad, K. 2007. Meeting the Universe Halfway: Quantum Physics and the Entanglement of Matter and Meaning. Duke University Press.

- Bledsoe, C.H. 1980. Women and Marriage in Kpelle Society. Stanford University Press.

- Buch, E.D. and Staller, K.M. 2014. What is Feminist Ethnography? In: Hesse-Biber, S. ed. Feminist Research Practice: A Primer. Thousand Oaks: SAGE, 107-144.

- Connell, P. 1997. Understanding Victimization and Agency: Considerations of Race, Class and Gender. PoLAR: Political \& Legal Anthropology Review. 20(2), 115-143.

- Derluyn, I., Vandenhole, W., Parmentier, S. and Mels, C. 2015. Victims and/or Perpetrators? Towards an Interdisciplinary Dialogue on Child Soldiers. BMC International Health o Human Rights. 15(28), 1-13.

- Enloe, C. 2014. Bananas, Beaches \& Bases: Making Feminist Sense of International Politics 2nd edn. Berkeley: University of California Press. · Enns, D. 2012. The Violence of Victimhood. Philadelphia: Penn State Press.

. Fierke, K. 2016. Is There Life Beyond Language? Discourses of Security. In: Schlag, G., Junk J. and 
Daase C. eds. Transformations of Security Studies. Abingdon: Routledge, 70-81.

- Govier, T. and Verwoerd, W. 2004. How Not to Polarize "Victims" and "Perpetrators". Peace Review: A Journal of Social Justice. 16(3), 371-377. - Haq, M.U. 1994. Human Development Report 1994: New Dimensions of Human Security. New York: United Nations Development Programme. - Henry, M. 2007. Gender, Security and Development. Conflict, Security \& Development. 7(1), 6184.

. Hudson, H. 2016. Decolonising Gender and Peacebuilding: Feminist Frontiers and Border Thinking in Africa. Peacebuilding. 4(2), 194-209. · Højgaard, L. and Juelskjær, M. 2012. The 'WHAT OF' and the 'WHAT IF' of Agential Realism. Kvinder, Kon \& Forskning. 1(2), 67-78.

· Højgaard, L. and Søndergaard, D.M. 2011. Theorizing the Complexities of Discursive and Material Subjectivity: Agential Realism \& Poststructural Analyses. Theory \& Psychology. 21(3), 338-354. - Korkoyah, D.T., Jr and Wreh, F.F. 2015. Ebola Impact Revealed: An Assessment of the Differing Impact of the Outbreak on the Women and Men in Liberia. UN Women, Oxfam International, Liberia Ministry of Gender and Development, Liberia Institute of Statistics and Geo-Information Services, Liberia WASH Consortium - Lamb, S. 1999. New Versions of Victims. New York: NYU Press.
- McNay, L. 2016. Agency. In: Disch, L. and Hawkesworth M. eds. The Oxford Handbook of Feminist Theory. Oxford University Press, 39-60. - Moser, C.O.N. and Clark, F.C. 2001. Victims, Perpetrators or Actors?. London: Zed Books Ltd. - Mutimer, D. 2017. Critical Security Studies In: Cavelty M. D. and Balzacq T. eds. Routledge Handbook of Security Studies. Abingdon: Routledge, 54-63.

- Nissim-Sabat, M. 2011. Neither Victim Nor Survivor: Thinking Toward a New Humanity. Lexington Books.

- Schott, R.M. 2013. 'Making Friends with the Beast?' Reflections on the Women, Peace and Security Agenda. Kvinder, Køn \&ু Forskning. 22(2), 16-28.

. Schott, R.M. 2015. 'Not Just Victims ... But': Toward a Critical Theory of the Victim. In: Widdows H. and Marway H. eds. Women and Violence. London: Palgrave Macmillan, 178-194. - Tickner, J.A. 1992. Gender in International Relations: Feminist Perspectives on Achieving Global Security. New York: Columbia University Press. · Tillmann-Healy, L.M. 2003. Friendship as Method. Qualitative Inquiry. 9(5), 72-749. . Wibben, A.T. 2011. Feminist Security Studies: A Narrative Approach. London: Routledge. 


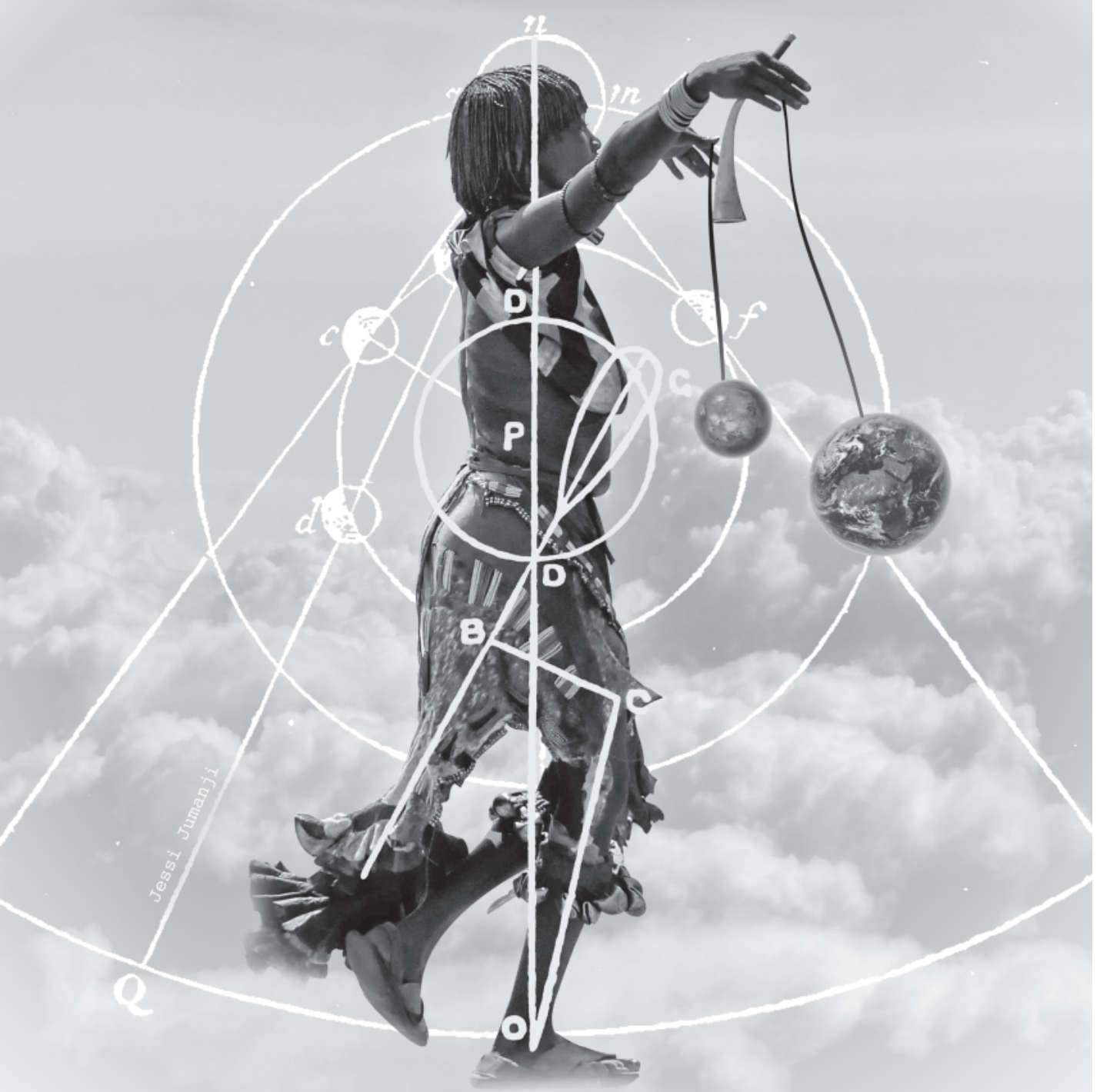

Jessi Jumanji “Maathematics3”. Collage Serie: Maathematics 